\title{
Lexical Errors Produced by Google Translate in Translating "Putri Serindang Bulan" to English Language
}

\author{
Kristiana Alasta \\ Universitas Bengkulu \\ kalasta@yahoo.com \\ Iis Sujarwati \\ Universitas Bengkulu \\ iissujarwati@unib.ac.id
}

\begin{abstract}
The purpose of this study was to analyze the lexical errors which was produced by google translate in translating "Putri Serindang Bulan" short story to English language as the target language. This study was conducted by using descriptive design with qualitatitive approach, which was done with consideration that the purpose of this research to analyze the lexical errors which produced by google translate in translating "Putri Serindang Bulan" short story to English language as the target language. This study was focused on describing the types of lexical errors produced by google translation in translating "Putri Serindang Bulan" short story to English language. In this research, the writer became the main instrument. This study obtained the data by reading "Putri Serindang Bulan" short story to understand the information of the short story, translating the "Putri Serindang Bulan" short story into English language use google translate, and then comparing the source text with the translation result to find out the translation accuracy and make the terms that were considered as inaccurate translation. The result showed that many errors were produced by google translate in translating the short story, the most frequent error found were incorrect word and missing word. In conclusion, this study suggest that the human translators must revise the translation result from machine translation.
\end{abstract}

Keywords: translation, lexical errors, google translate.

\section{A. Introduction}

In Oxford Advanced Learner's Dictionary (2000) translation is defined as the process of changing something that is written or spoken into another language. Newmark (1998) in Ilzamudin's states that translation is a process of rendering the meaning of a text into another text language in the way that the author intended the text. Rochayah (2000) in Hijriyah's also explains that translation is the replacement of textual material in one language (as a source language) by equivalent textual material in another language (as target language).

From the theories above, the writer conclude that the translation is a process of language meaning transferring including the linguistic entities from source language into target language without forgetting their equivalences. The translation must still convey the information from the source language precisely, fluently and in correct 
structure. Nida (1964) in Saleh and Weda's says that a translator will translate successfully if the translator capable in transfer messages with equivalent, form and style from source language into target language and translate them employing an appropriate framework to provide thought and culture that may not exist in te target language.

The translation can be said as an art. There is a close relationship between writers' language taste and translators' language taste. In other words, the translation can be said as a fashion of someone's thought. If the fashion is good and suitable with the situation, so it will be beautiful and interesting. The most basic thing in translating is the ability to think and the way to transfer the result of thougths into good sentences and expressions. Nowadays, the demands of translation in text varieties become a must; it causes the translation activities grow up like the mushrooms in rainy seasons.

Machine translation is software that is able to translate the text automatically without human's intervention on its process. It is a tool which can help the human translators in translating process and can make this process done faster, because with the capabilities of a machine translation a text with hundreds of words can be translated in few second only. It is surely that in terms of speed, it would be very different if we compare the use of this machine translation process which is done manually by the human translator.

In this globalization era, there are so many humans use computer aids to support their activities, including in the translation process itself. The computer has been an amalgamated part of the infrastructure needed by translators, but the translators should know about the knowledge and skills which linked to the translation technologies. This technology has a role as an aid for the translation process through software which consist of two main panels; they are input panel (source language) and output pannel (target language).

There are several products of machine translation which can help the human translators in their job, one of them is Google Translate. Google Translate can be accessed every time and every where. Doing translation use google translate can make the process itself easier and faster. Actually, it is not a rival of the human translator, but it is a help sustain in order to translate the text quickly and effectively.

But, in some cases there are many errors which will be found when doing the translation process with google translate, such as low level of accuracy in translation, some contexts of the translation cannot be understood, and some cultural differences and vocabularies cannot be translated directly. It means that the translation must be invariably be revised by the human translators. Because of that, some people assume that the translation is an activity which requires an understanding of meaning and context which only humans can do, and it cannot be replaced by machines, no matter how shopisticated the machines are.

The translators must have a good qualification in understanding both the source languageand the target language. In translating a written text, there are intralinguistic and extralinguistic factors which must be understood before the ideas of the writers are transferred into teh target languange. The language as an object of the translation is part of culture and therefore translation from one language to another language cannot be done adequately, without have a good knowledge of the culture and structure of the two languages. 
The errors in language relate to things that are in accordance with the rules. In the translation principle, it is the process of transferring the message or meaning from the source language into the target language by using lexical or vocabulary elements. The acceptable and good translation requires an adequate lexical understanding because of its central role in the translation. The correct choice of lexical determines the transfer process of the message is conveyed.

According to Halliday and Yallop (2007) in Ramli's, the lexical or vocabulary, meaning and form are the main elements in the translation. The choices of the right lexical elements determines the success of the message delivery from the source language to the target language, and the errors of the lexical use will make the errors of message delivery from the source language.

Vilar at al (2006) cited in Susanti's have split the categories of errors in translating into five big classes, they are missing wors, word order error, incorrect words, unknown words and punctuation errors.

The first category is missing word. It means when translating a text by using google translate some words are missing in generate sentences and this can significantly change the sentences meanings of the text. The second category is word order error. The word order is about the sequence of the words in the sentences. In making a sentence, there are some rules that must be obeyed. It is a crucial thing to make good sentences. The third category is incorrect word. This incorrect words will be found when google translate is unable to find the correct translation of the words given. The fourth category is unknown words. This error occurs when google translate cannot translate the source words into the target words. The fifth category is punctuation error. In using the machine translation product this error is not infrequent to occur.

There are some related previous studies conducted the use of machine translation products in translating. The first study is a study conducted by Silaholo (2015). The result of this study was the accuracy translation machine tool can translate Bahasa Indonesia text to English around $70 \%$. The second one is a study conducted by El-Banna and Naeem (2016). The result of this study was common errors handled were classified into three categories: syntatic errors, semantic errors and pragmatic errors. The third study is a study conducted by Susanti (2018). The result of this study showed that instagram machine translation produced so many errors, in addition missing words and incorrect words are the most frequent error found. The fourth study is a study conducted by Griffith (2020). The result of this study was the most frequent errors produced by Google Translate are those of capitalization, punctuation and fragmentation.

By considering the explanation and the related previous study above, the writer encouraged to conduct a mini research on the lexical errors produced in translating "Putri Serindang Bulan" short story into English language by using google translate. The current study is, therefore, guided by the following objective, to analyze the lexical errors which is produced in translating "Putri Serindang Bulan" short story to English language as the target language. The result of this study is expected to become evidence and can expand the knowledge about lexical errors produced in tanslating by using the machine translation product namely google translate. 


\section{B. Research Methodology}

This study was conducted by using descriptive design with qualitatitive approach. Moleong (2011) in Muhammad's argues that the qualitative research emphasizes understanding the phenomenon of research subjects, such as behavior, perception, motivation, action and the others holistically and by means of descriptions in the form of words and language, in special natural context.

This study was done with consideration that the purpose was to analyze the lexical errors which is produced in translating "Putri Serindang Bulan" short story to English language as the target language. The qualitative data was gathered to look for the phenomena of google translation output. This study was focused on describing the types of lexical errors produced by google translation in translating "Putri Serindang Bulan" short story to English language.

In this study, the result of translating by google translate became the source of the data. To get the data, the writer did some steps. The first step was the writer read "Putri Serindang Bulan" short story to understand the information of the story. It was useful to revise the lexical errors which are probably produced by google translate. The second step was the writer translated "Putri Serindang Bulan" short story with google translate. The writer translated the paragraph one by one. The third step was the writer wrote the translation result. The fourth step was the writer compared the translation result with the source text, to find out the inaccurate translation.

After comparing stage, the writer analyzed the data. The writer analyzed the lexical errors which produced by google translate in translating "Putri Serindang Bulan" short story. In this identification stage, the writer used the theory which is proposed by Vilar at al (2006) cited in Susanti's. According to him, these are five big categories of lexical errors; they are missing words, incorrect words, word order error, unknown words and punctuation errors.

\section{Result and Discussion \\ 1. Result}

In this mini research, the writer analyzed the data which related to the research question. The writer translated the text of "Putri Serindang Bulan" short story into English using Google Translate and then analyzed it using types of lexical errors by Vilar et.al. The text of "Putri Serindang Bulan" short story was retrivied from https://pedomanbengkulu.com/2018/03/legenda-putri-serindang-bulan-dalam-ceritarakyat-bengkulu/.

\section{Table 1. Translation Result}

\begin{tabular}{|c|l|}
\hline Paragraph & \multicolumn{1}{|c|}{ Target Language (TL) } \\
\hline 1 & $\begin{array}{l}\text { Long ago in Bengkulu lived seven sisters. They are the daughters of } \\
\text { King Wawang. Of the seven children, Putri Serindang Bulan is the } \\
\text { youngest daughter. Putri Serindang Bulan is also famous for being the } \\
\text { most beautiful. Many men have wanted to propose to her but she } \\
\text { always refused on the grounds that she didn't want to step over her six } \\
\text { older siblings. }\end{array}$ \\
\hline 2 & Her six older siblings are actually planning to get married after Putri \\
\hline
\end{tabular}




\begin{tabular}{|c|c|}
\hline & $\begin{array}{l}\text { Serindang Bulan gets married. They then asked Putri Serindang Bulan } \\
\text { to marry first. }\end{array}$ \\
\hline 3 & $\begin{array}{l}\text { "O my brother, many men have wanted to propose to you. Get married } \\
\text { right away. Don't worry, we will all get married. " Said the oldest } \\
\text { brother. }\end{array}$ \\
\hline 4 & $\begin{array}{l}\text { "Okay, brother, I'm getting married. I hope you all quickly get a match. } \\
\text { " Putri Serindang Bulan agreed. }\end{array}$ \\
\hline 5 & $\begin{array}{l}\text { Raja Wawang then immediately spread the news that his youngest } \\
\text { daughter, Serindang Bulan, was ready to get married. The youths were } \\
\text { happy. Not long after, a Prince Charming came to see King Wawang to } \\
\text { propose to Putri Serindang Bulan. Putri Serindang accepted the Prince } \\
\text { Charming's proposal. Then the Kingdom immediately prepared a } \\
\text { festive wedding party. }\end{array}$ \\
\hline 6 & $\begin{array}{l}\text { However, suddenly a strange incident happened to Putri Serindang } \\
\text { Bulan. On the eve of the wedding, his face turned ugly. The princess's } \\
\text { body was also covered with skin diseases. }\end{array}$ \\
\hline 7 & $\begin{array}{l}\text { "What's wrong with your body, O Princess? Your body has a skin } \\
\text { disease. " asked the Prince in amazement. }\end{array}$ \\
\hline 8 & $\begin{array}{l}\text { "I also do not know. When I wake up in the morning, suddenly my face } \\
\text { becomes ugly, my body is covered with skin diseases. " said Putri } \\
\text { Serindang Bulan. }\end{array}$ \\
\hline 9 & $\begin{array}{l}\text { The prince was so disappointed that he decided to cancel their } \\
\text { marriage. }\end{array}$ \\
\hline 10 & $\begin{array}{l}\text { But strangely, after the Prince Charming left, Serindang Bulan's face } \\
\text { was beautiful again. The princess's body becomes healthy as before. } \\
\text { Every time a man proposes, Serindang Bulan's face will turn bad, but } \\
\text { will return to beauty if the marriage is canceled. This was repeated } \\
\text { nine times. The family, especially the six sisters, felt ashamed. }\end{array}$ \\
\hline 11 & $\begin{array}{l}\text { One day, the six Serindang Bulan sisters held a secret meeting. The } \\
\text { meeting resulted in a decision that they had to get rid of Serindang } \\
\text { Bulan because it was considered a source of trouble for the kingdom. } \\
\text { One of them, Karang Nio, initially refused to get rid of Serindang } \\
\text { Bulan. Karang Nio is indeed the closest to Serindang Bulan. However, } \\
\text { with his refusal, Karang Nio actually got the task to get rid of } \\
\text { Serindang Bulan. The five brothers asked for proof in the form of a } \\
\text { blood tube and slices of Serindang Bulan's ear, as a sign that he had } \\
\text { gotten rid of her. }\end{array}$ \\
\hline 12 & $\begin{array}{l}\text { With a heavy heart, Karang Nio fulfilled the request of his brothers. } \\
\text { One day, Karang Nio took Serindang Bulan for a walk. Initially } \\
\text { Serindang Bulan was not suspicious, however, gradually Serindang } \\
\text { Bulan was afraid because Karang Nio invited her to enter the forest. } \\
\text { Karang Nio looks very restless. Finally he told Serindang Bulan that he } \\
\text { had a job to get rid of him. }\end{array}$ \\
\hline 13 & $\begin{array}{l}\text { "If it has become a decision, big brother, then do your job Sis." said } \\
\text { Serindang Bulan sadly. }\end{array}$ \\
\hline
\end{tabular}




\begin{tabular}{|c|c|}
\hline 14 & $\begin{array}{l}\text { Karang Nio finally decided to trick his brothers. He slaughtered a } \\
\text { coyote. He kept the coyote's blood in a tube. Then he injured Serindang } \\
\text { Bulan's ear. The ears of the Serindang princess will be brought by him } \\
\text { as proof that he has carried out his duty to get rid of him. Karang Nio } \\
\text { ordered Serindang Bulan to go on a raft from the Ulau Deus river. }\end{array}$ \\
\hline 15 & $\begin{array}{l}\text { Karang Nio immediately returned to the palace. Arriving at the palace, } \\
\text { he showed evidence of a blood vessel and ears of Serindang Bulan to } \\
\text { his brothers. All of her brothers were happy. }\end{array}$ \\
\hline 16 & $\begin{array}{l}\text { While in the forest, Serindang Bulan went on a raft on the river. He } \\
\text { finally came down to the Muara One year area. There, Serindang } \\
\text { Bulan climbed a cliff. On the cliff, the princess made a house for her to } \\
\text { live in. }\end{array}$ \\
\hline 17 & $\begin{array}{l}\text { A year has passed since Serindang Bulan left the palace. Once upon a } \\
\text { time, a boat belonging to Raja Indrapura named Tuanku Raja Alam } \\
\text { passed through Muara Setahun. The King saw a shining light from the } \\
\text { top of the hill. Out of curiosity, the King pulled over and then got off } \\
\text { the boat. He then climbed the cliff from the source of the shining light. } \\
\text { Arriving at the top of the waterfall, the King saw a house. The king } \\
\text { knocked on the door of the house. From the house Serindang Bulan } \\
\text { emerged which surprised the King. }\end{array}$ \\
\hline 18 & $\begin{array}{l}\text { "O beautiful girl, I did not think that the light on the cliff was actually } \\
\text { from you." said the King. }\end{array}$ \\
\hline 19 & $\begin{array}{l}\text { After getting acquainted, Putri Serindang Bulan then recounted what } \\
\text { happened to her. The story of Serindang Bulan moved the King to tears } \\
\text { and then invited him to live in the Indrapura Kingdom. Serindang } \\
\text { Bulan agreed. }\end{array}$ \\
\hline 20 & $\begin{array}{l}\text { Arriving at the Indrapura Kingdom, the King held a meeting. The King } \\
\text { told about the problem of Serindang Bulan. The King wishes to } \\
\text { propose to Serindang Bulan. The Royal Kings proposed to look at the } \\
\text { situation for three days to see if Serindang Bulan's face would turn bad } \\
\text { again. After waiting for three days, it turns out that Serindang Bulan's } \\
\text { face is still beautiful. Finally, the rulers married the King to Serindang } \\
\text { Bulan. }\end{array}$ \\
\hline 21 & $\begin{array}{l}\text { The Penghulu asked the King to inform the guardian of Serindang } \\
\text { Bulan. The king then sent a messenger to Raja Wawang's place to } \\
\text { inform him about the wedding plans of Serindang Bulan with Raja } \\
\text { Alam. Hearing the news, Serindang Bulan's brothers were shocked. } \\
\text { They blamed Karang Nio for failing to get rid of Serindang Bulan. }\end{array}$ \\
\hline 22 & $\begin{array}{l}\text { "Never mind my brothers. Stop fighting us. We'd better go together to } \\
\text { attend Serindang Bulan's wedding. " said Karang Nio. The Karang Nio } \\
\text { brothers finally said yes. }\end{array}$ \\
\hline 23 & $\begin{array}{l}\text { Then the six sisters departed. When they arrived in the Indrapura } \\
\text { Kingdom, they immediately met Tuanku Raja Alam. The six sisters } \\
\text { asked for a dowry in the form of gold as a condition for marrying their } \\
\text { younger brother, Serindang Bulan. }\end{array}$ \\
\hline
\end{tabular}




\begin{tabular}{|c|l|}
\hline 24 & $\begin{array}{l}\text { Raja Alam agreed to the dowry request of the six sisters but on one } \\
\text { condition, they had to identify their own sister, Serindang Bulan. If } \\
\text { not, then they will all be punished. The king then prepared six girls } \\
\text { who were dressed and their faces resembled Serindang Bulan. They } \\
\text { were confronted by the six sisters of Serindang Bulan. The six } \\
\text { Serindang Bulan sisters were asked to show them the real Serindang } \\
\text { Bulan. }\end{array}$ \\
\hline 25 & $\begin{array}{l}\text { The five sisters were confused because they didn't know the real } \\
\text { Serindang Bulan. But Karang Nio remembered that he had injured } \\
\text { Serindang Bulan's ear. And sure enough, there is one girl who has a } \\
\text { scar on her ear which means she is the real Serindang Bulan. Finally, } \\
\text { the daughter of Serindang and Karang Nio hugged her while crying, } \\
\text { letting go of homesickness. }\end{array}$ \\
\hline 26 & $\begin{array}{l}\text { "Very nice. That means you still recognize Serindang Bulan. I will } \\
\text { fulfill the dowry by giving the gold you wish. I assume there is no } \\
\text { longer any grudge between you. " said the King. }\end{array}$ \\
\hline 27 & $\begin{array}{l}\text { Finally Tuanku Raja Alam married Serindang Bulan. Meanwhile the } \\
\text { six sisters received a bamboo jar filled with gold. Serindang Bulan } \\
\text { doesn't hold a grudge against her brothers at all. Even though he was } \\
\text { married and lived apart from his brothers, he still often sent them gifts. }\end{array}$ \\
\hline
\end{tabular}

From the result of translation above, there were many errors found. These errors occured in accordance with the result of Silaholo's study in 2015 that the accuracy translation machine tool can translate Bahasa Indonesia text to English around 70\%.

The errors in language relate to things that are in accordance with the rules. In the translation principle, it is the process of transferring the message or meaning from the source language into the target language by using lexical or vocabulary elements. The acceptable and good translation requires an adequate lexical understanding because of its central role in the translation. The correct choice of lexical determines the transfer process of the message is conveyed.

Table 2. Research finding - categories of lexical errors

\begin{tabular}{|l|c|c|}
\hline \multicolumn{1}{|c|}{ Error Categories } & Number of Error & Persentage of Error \\
\hline Missing word & 8 & $15,09 \%$ \\
\hline Word order error & 5 & $9,43 \%$ \\
\hline Incorrect word & 37 & $69,81 \%$ \\
\hline Unknown word & 1 & $1,89 \%$ \\
\hline Punctuation error & 2 & $3,78 \%$ \\
\hline
\end{tabular}

Based on the table above, the most frequent category of error found was incorrect word which the total result $37(69,81 \%)$ and followed by missing word which the total result $8(15,09 \%)$. This result was suitable with the result of the study which was conducted by Susanti (2018), the result of her study shows that instagram machine translation produced so many errors, in addition incorrect words and missing word were the most frequent error found.

\section{Discussion}

In paragraph 1, google translate has translated the first sentence "Long ago in Bengkulu lived seven sisters". There were missing words "time" and "there" here. A 
missing word was produced when google translate system missing the word in generated sentence. This should be "Long time ago in Bengkulu there lived seven sisters". Google translate has translated the third sentence into "Of the seven children, Putri Serindang Bulan is the youngest daughter". There was incorrect word here, the word "of" must be changed to word "from", this should be "From the seven children, Putri Serindang Bulan is the youngest daughter". Then, google translate has translated the fifth sentence into "Many men who have wanted to propose to her but she always refused on the grounds that she didn't want to step over her six older siblings". There were missing word "there are" and incorrect word "on the grounds" here, this should be "There are many men have wanted to propose her but she always refused by reason that she didn'n want to get married before her six siblings".

In paragraph 2, google translate has translated the first sentence into "Her six older siblings are actually planning to get married after Putri Serindang Bulan gets married". There was incorrect word "are" here. An incorrect word was produced when google translate system did not able to find the correct translation of word given. So, this should be "Her six olders siblings were actually planning to get married after Putri Serindang Bulan got married".

In paragraph 3, google translate has translated has translated the sentences into “ 'O my brother, many men have wanted to propose to you. Get married right away. Don't worry, we will all get married.' Said the oldest brother". There were incorrect word, missing word and word order error here. The word "brother" was incorrect because Putri Serindang Bulan was a woman so it must be changed to word "sister", there was also missing word "there are", and word order error of "we will all". This should be " 'O my sister, there are many men who have wanted to propose you. Get married right away. Don't worry, we all will get married soon.' said the oldest sister".

In paragraph 4, google translate has translated the sentences into "Okay, brother, I'm getting married. I hope you all quickly get a match.' Putri Serindang Bulan agreed". There were incorrect word "brother" and punctuation error "okey, brother," here. The punctuation error was produced when google translation system unable to put the correct punctuation in the sentence. So, this should be "Okay sister, I'm getting married. I hope you all quickly get your soulmate.' Putri Serindang Bulan aggreed".

In paragraph 5, google translate has translated the third sentence into "Not long after, a Prince charming came to see King Wawang to propose to Putri Serindang Bulan". There are word order error "prince charming", it must be adjective before noun and there was incorrect word "see" here, this should be "Not long after, a charming Prince came to meet King Wawang to propose Putri Serindang Bulan". Then, google translate has translated the fourth into "Putri Serindang Bulan accepted the Prince Charming's proposal". There are word order error "prince charming" and missing word here, this should be "Putri Serindang Bulan accepted the charming Prince's marriage proposal".

In paragraph 8, google translate has translated the sentence into " 'I also do not know. When I wake up in the morning, suddenly my face becomes ugly, my body is covered with skin diseases.' said Putri Serindang Bulan". There was incorrect word "wake" here, this should be " "I also do not know. When I woke up in the morning, 
suddenly my face became ugly, my body was covered with skin diseases.' Said Putri Serindang Bulan.

In paragraph 9, google translate has translated the sentence into "The prince was so disappointed that he decided to cancel their marriage". There was incorrect word "that" here, this should be "The prince was disappointed so he decided to cancel their marriage".

In paragraph 10, google translate has translated the first sentence into "But strangely, after the Prince charming left, Putri Serindang Bulan's face was beautiful again". There was word order error "prince charming" here, this should be "But strangely, after the charming Prince left, Putri Serindang Bulan's face was beautiful again". Then, google translate has translated the fourth and fifth sentences into "This was repeated nine times. The family, especially the six sisters felt ashamed". There was missing word here, this should be "This was repeated up to nine times. The family, especially the six older sisters felt ashamed".

In paragraph 11, google translate has translated the first sentence into "One day, the six Serindang Bulan sisters held a secret meeting". There was a punctuation error here, it must be "One day, the six Putri Serindang Bulan's sisters held a secret meeting". Google translate has translate the fifth sentence into "However with his refusal, Karang Nio actually got the task to get rid of Putri Serindang Bulan". There was incorrect word "his", because Karang Nio was a woman so the word "his" must be changed to "her". This should be "However with her refusal, Karang Nio actually got the task to get rid of Putri Serindang Bulan". Then, google translate has translated the sixth sentence into "The five brothers asked for proof in the form of a blood tube and slices of Putri Serindang Bulan's ear, as a sign that he had gotten rid of her". There were incorrect words "brothers" and "he", this should be "The five sisters asked for proof in the form of a blood tube and slices of Putri Serindang Bulan's ear, as a sign that she had gotten rid of her".

In paragraph 12, google translate has translated the first sentence into "With a heavy heart, Karang Nio fulfilled the request of his brothers". There was incorrect words "his brothers" here, this should be "With a heavy heart, Karang Nio fulfilled the request of her sisters". Then, the third sentence was translated into "Initially Putri Serindang Bulan was not suspicious, however, gradually Putri Serindang Bulan was afraid because Karang Nio invited her to enter the forest". There was incorrect word "gradually" here, this should be "Initially Putri Serindang Bulan was not suspicious however, in the long run Putri Serindang Bulan was afraid because Karang Nio invited her to enter the forest". The fifth sentence was translated into "Finally he told Putri Serindang Bulan that he had a job to get rid of him". There were incorrect words "he", "his" and "him" here, this should be "Finally she told Putri Serindang Bulan that she had a job to get rid of her".

In paragraph 14, google translate has translated the first sentence into "Karang Nio finally decided to trick his brothers". There were incorrect words "his brothers" here, this should be "Karang Nio finally decided to trick her sisters". The second sentence was translated into "He slaughtered a coyote". There was incorrect word "he" here, this should be "She slaughtered a coyote". Then, the third sentence was translated into "He kept the coyote's blood in a tube". There was incorrect word "he" here, this 
should be "She kept the coyote's blood in a tube". The fourth sentence was translated into "Then he injured Serindang Bulan's ear". There was incorrect word "he" here, this should be "Then she injured Serindang Bulan's ear". Then, google translate has translated the fifth sentence into "The ears of the Serindang princess will be brought by him as proof that he has carried out his duty to get rid of him". There were incorrect words "him" , "his" and "he" here, this should be "The ears of the Serindang princess will be brought by her as proof that she has carried out her duty to get rid of her".

In paragraph 15, google translate has translated the second and third sentence into "Arriving at the palace, he showed evidence of a blood vessel and ears of Serindang Bulan to his brothers. All of her brothers were happy". There were incorrect words "he", "his" and "brothers", this should be "Arriving at the palace, she showed evidence of a blood vessel and ears of Serindang Bulan to her sisters. All of her sisters were happy".

In paragraph 16, google translate has translated the second sentence into "He finally came down to the Muara One year area". There was incorrect word "he" and for a name of place it can not be translated, so this should be "She finally came down to the Muara Setahun area".

In paragraph 19, google translate has translated the first sentence into "After getting acquainted, Putri Serindang Bulan then recounted what happened to her". There was incorrect word "recounted" here, this should be "After getting acquainted, Putri Serindang Bulan then told what happened to her". Then, the second sentece was translated into "The story of Serindang Bulan moved the King to tears and then invited him to live in the Indrapura Kingdom". There were incorrect words, this should be "The story of Serindang Bulan made the King touched then asked her to live in Indrapura Kingdom".

In paragraph 21, google translate has translated the first sentence into "The Penghulu asked the King to inform the guardian of Serindang Bulan". There was unknown word "penghulu". The unknown word was produced when google translate system did not find the translation of word given. This should be "The head of marriage asked the King to inform the guardian of Serindang Bulan". Then the third sentence was translated into "Hearing the news, Serindang Bulan's brothers were shocked". There was incorrect word "brothers" here, this should be "Hearing the news, Serindang Bulan's brothers were shocked".

In paragraph 22, google translate has translated the first sentence into "Never mind my brothers". There was incorrect word "brothers" here, this should be "Never mind my sisters. The second sentence was translated into "Stop fighting us". There was incorrect word here, this should be "Stop our fighting". Then, google translate has translted the fourth sentence into "The Karang Nio brothers finally said yes". There was incorrect word "brothers" here, this should be "The Karang Nio sisters finally said yes".

In paragraph 23, google translate has translated the third sentence into "The six sisters asked for a dowry in the form of gold as a condition for marrying their younger brother, Serindang Bulan". There was incorrect word "brother" here, this should be "The six sisters asked for a dowry in the form of gold as a condition for marrying their younger sister, Serindang Bulan" 
In paragraph 24, google translate has translated the first sentence into "Raja Alam agreed to the dowry request of the six sisters but on one condition, they had to identify their own sister, Serindang Bulan". There was missing word "younger" here, this should be "Raja Alam agreed to the dowry request of the six sisters but on one condition, they had to identify their own younger sister, Serindang Bulan". Then the second sentence in this paragraph was translated into "If not, then they will all be punished". There were incorrect word and word order error here, this should be "If not, then they all would be punished".

In paragraph 26, google translate has translated the second sentence into "But Karang Nio remembered that he had injured Serindang Bulan's ear". There was incorrect word "he" here, this should be "But Karang Nio remembered that she had injured Serindang Bulan's ear".

In paragraph 27, google translate has translated the third sentence into "Serindang Bulan doesn't hold a grudge against her brothers at all". There were incorrect words here, this should be "Serindang Bulan did not hold a grudge against her sisters at all". Then, google translated has translated the fourth sentence in this paragraph into "Even though he was married and lived apart from his brothers, he still often sent them gifts". There were incorrect words "he", "his" and "brothers" here, this should be "Even though she was married and lived apart from her sisters, she still often sent them gifts".

\section{Conclusion and Suggestion}

The translation is a process of language meaning transferring including the linguistic entities from source language into target language without forgetting their equivalences. The translation must still convey the information from the source language precisely, fluently and in correct structure. The translation can be said as an art. There is a close relationship between writers' language taste and translators' language taste. The use of machine translation, especially Google translate, becomes something normal that can be accessed in every time and everywhere. As a product of the machine translation, Google translate surely has the possibility in producing some errors in translating the source language into the target language. The result of this study showed that the most frequent error found were incorrect word and missing word. This result was suitable with the result of the study which was conducted by Susanti (2018), the result of her study shows that instagram machine translation produced so many errors, in addition incorrect words and missing word were the most frequent error found.

In some cases there are many errors which will be found when doing the translation process with google translate, such as low level of accuracy in translation, some contexts of the translation cannot be understood, and some cultural differences and vocabularies cannot be translated directly. It means that the translation must be invariably be revised by the human translators. Because of that, some people assume that the translation is an activity which requires an understanding of meaning and context which only humans can do, and it cannot be replaced by machines, no matter how shopisticated the machines are. 
Jadila: Journal of Development and Innovation in Language and Literature Education

Publisher: Yayasan Karinosseff Muda Indonesi
E-ISSN: 2723-6900

P-ISSN: 2745-9578

Volume 2 Number 2, 2021

Page 200-211

\section{References}

AS, Homby. (2000). Oxford Advanced Learner's Dictionary. Oxford University.

El-Banna, Adel, I., Naeem, A., Marwa. (2016). Machine Translation as a Model for Overcoming Some Common Errors in English-into-Arabic Translation among EFL University Freshmen. Published Article: Kafr El-Sheikh University

Griffith, K. (2020). Google Translate and Translation Quality: A Case of Translating Academic Abstracts from Thai to English. PASAA Volume 60 E-ISSN: 22870024.

Hijriyah, U. (2016). Metode Penelitian dan Terjemahan. Lampung: IAIN Raden Intan Lampung.

Ma'mur, I. (2014). Konsep Dasar Penerjemahan: Tinjauan Teoritis. Al-Qalam: Published Article Vol. 21 No. 102.

Angk, M.A. (2013). Kesadaran Hukum Masyarakat Kampung. Universitas Pendidikan Indonesia.

Ramli., Puspa Sari. (2013). Kesalahan Leksikal dalam Terjemahan Teks Bahasa Indonesia-Inggris Formal. Published Article: Universitas Lakdende Unahaa.

Saleh, J. Noer, Weda Sukardi. (2013). Indonesian Poetry Translation: The Problem Within. Published Article.

Susanti, E. (2018). Lexical Errors Produced by Instagram Machine Translation. Thesis: Universitas Islam Negeri Malik Maulana Ibrahim Malang.

Silaholo, B. G. (2015). The use of Translation Machine by Students of English Education Study Program of Bengkulu University. Unpublished Thesis. Bengkulu: Faculty of Teacher Training and Education, Universitas Bengkulu.

. https://pedomanbengkulu.com/2018/03/legenda-putri-serindang-bulan-dalamcerita-rakyat-bengkulu 